\title{
Effects of Full-Length Kisspeptin Administration on Follicular Development in Japanese Black Beef Cows
}

\section{Yousuke NANIWA ${ }^{1,2)}$, Keisuke NAKATSUKASA ${ }^{1)}$, Shohei SETSUDA ${ }^{3)}$, Shinya OISHI ${ }^{3)}$, Nobutaka FUJII'), Fuko MATSUDA ${ }^{1}$, Yoshihisa UENOYAMA ${ }^{1}$, , Hiroko TSUKAMURA ${ }^{1 \text { ), }}$ Kei-ichiro MAEDA ${ }^{4)}$ and Satoshi OHKURA ${ }^{1)}$}

\author{
${ }^{1)}$ Graduate School of Bioagricultural Sciences, Nagoya University, Nagoya 464-8601, Japan \\ 2) Research Fellow of the Japan Society for the Promotion of Science \\ ${ }^{3)}$ Graduate School of Pharmaceutical Sciences, Kyoto University, Kyoto 606-8501, Japan \\ ${ }^{4)}$ Graduate School of Agricultural and Life Sciences, The University of Tokyo, Tokyo 113-8657, Japan
}

\begin{abstract}
Kisspeptin is a key molecule that stimulates gonadotropin secretion via release of gonadotropin-releasing hormone $(\mathrm{GnRH})$. In the present study, our aim was to investigate whether kisspeptin has stimulatory effects on follicular development via GnRH/gonadotropin secretion in cows. Japanese Black beef cows were intravenously injected with full-length bovine kisspeptin [Kp-53 $(0.2$ or $2 \mathrm{nmol} / \mathrm{kg})]$ or vehicle 5 days after they exhibited standing estrus (Day 0$)$. In cows injected with $\mathrm{Kp}-53$ at $2 \mathrm{nmol} / \mathrm{kg}$, the follicular sizes of the first dominant follicles increased on Day 6 and thereafter. Ovulation of the first dominant follicle occurred in 1 out of 4 cows treated with Kp-53 at $2 \mathrm{nmol} / \mathrm{kg}$. Injection of Kp-53 at $2 \mathrm{nmol} / \mathrm{kg}$ increased the concentration of plasma luteinizing hormone ( $\mathrm{LH}$ ) but not follicle-stimulating hormone, over a 4-h period following injection in all cows. The present study suggests that administration of full-length kisspeptin causes LH secretion, which is sustained for a few hours, and it is capable of stimulating follicular development and/or ovulation.
\end{abstract}

Key words: Cattle, Follicular development, Gonadotropin, Kisspeptin, Ovulation

(J. Reprod. Dev. 59: 588-594, 2013)

l: the ovaries of cows, antral follicle growth is stimulated by the actions of gonadotropin. Basal release of gonadotropin-releasing hormone (GnRH) from the hypothalamus into the hypophyseal portal circulation maintains tonic gonadotropin secretion from the pituitary [1], resulting in follicular development and steroidogenesis in the ovaries [2]. In the last decade, kisspeptin, a peptide encoded by the Kiss 1 gene, has attracted attention as a key molecule in the regulation of $\mathrm{GnRH} /$ luteinizing hormone $(\mathrm{LH})$ release in many mammalian species [3-5], including rodents, ruminants and primates. Several lines of evidence have shown that kisspeptin directly stimulates GnRH release via the kisspeptin receptor GPR54 (also described as Kiss 1 receptor) [6-8]. The loss of Kiss 1 gene function in mice $[9,10]$ or GPR54 in humans $[11,12]$ causes hypogonadotropic hypogonadism, suggesting that kisspeptin-GPR54 signaling plays a pivotal role in the regulation of reproductive functions. Indeed, local infusion of anti-kisspeptin antibody blocks the preovulatory [13] and estradiol-induced [14] LH surge in rats. Central infusion of a kisspeptin antagonist inhibits the estradiol-induced LH surge in sheep [15]. These reports strongly suggest that kisspeptin signaling is involved in the central mechanism regulating the $\mathrm{GnRH} / \mathrm{LH}$ surge and ovulation.

Kisspeptin neurons could also be involved in the regulation

Received: May 31, 2013

Accepted: August 29, 2013

Published online in J-STAGE: October 10, 2013

(C2013 by the Society for Reproduction and Development

Correspondence: S Ohkura (e-mail: saohkura@agr.nagoya-u.ac.jp) of pulsatile GnRH release, which is essential in maintenance of the sensitivity of the pituitary gonadotroph to GnRH stimulation, and therefore follicular development and maturation. Repetitive administration of kisspeptin induces pulsatile $\mathrm{GnRH} / \mathrm{LH}$ release in rats [16], sheep [17] and monkeys [18]. A GPR54 antagonist blocks endogenous GnRH/LH pulses in the above species [19, 20]. An electrophysiological study in goats demonstrated that the periodic increase in multiple-unit neuronal activity in the hypothalamic arcuate nucleus, where kisspeptin neurons reside, is temporally associated with LH pulses [21]. These studies suggest that kisspeptin neurons play a pivotal role in regulating pulsatile $\mathrm{GnRH} / \mathrm{LH}$ release. However, it has not yet been shown whether activation of kisspeptin-GPR54 signaling has an effect on ovarian follicular growth and maturation.

The aim of the present study was to investigate whether follicular development is facilitated by peripheral administration of kisspeptin. Here, we used ovary-intact beef cows as a model, which allows monitoring of follicular dynamics in the same individual. We synthesized and used full-length bovine kisspeptin (Kp-53) to examine the effects of intravenous injection of the peptide on ovarian activity and gonadotropin secretory response in cows. We argued that if the stimulatory effects of Kp-53 administration on gonadal functions were confirmed in cows, then kisspeptin would be applicable as a novel drug for stimulating follicular development in veterinary therapy for farm animals. 


\section{Materials and Methods}

\section{Animals}

All experiments were performed on 6- to 11-year-old Japanese Black beef cows $(n=5)$ weighing between 372 and $504 \mathrm{~kg}$. All cows had three waves of follicular growth during the estrous cycle. Cows were maintained under natural conditions at the Field Science Center, Graduate School of Bioagricultural Sciences, Nagoya University, Japan. Cows were fed twice daily with grass silage or hay diet and had $a d$ lib access to water and supplemental minerals. At least 1 day prior to the experiment, a 14-gauge catheter (length, $70 \mathrm{~cm}$; CV Legaforce DX, Terumo, Tokyo, Japan) was placed into a jugular vein of the cows for drug injection and blood sampling. Some cows were used repetitively for the experiment. Two out of 5 cows were injected with all doses of Kp-53 and vehicle. Two cows were injected with vehicle and low or high doses of Kp-53, respectively. The remaining cow was injected with a high dose of Kp-53. All experiments were approved by the Committee for the Care and Use of Experimental Animals of the Graduate School of Bioagricultural Sciences, Nagoya University.

\section{Reagents}

Bovine Kp-53 (cDNA sequence of bovine KISS1 gene; GenBank accession number, AB466319) was prepared using the standard protocol for Fmoc-based peptide synthesis. Briefly, a protected peptide resin for Kp-53 was constructed on NovaSyn ${ }^{\circledR}$ TGR resin using HBTU/HOBt/DIEA. The resin was then treated with TFA/m-cresol/ thioanisole/1,2-ethanedithiol $/ \mathrm{H}_{2} \mathrm{O}(80: 5: 5: 5: 5)$ for $2 \mathrm{~h}$. The crude product was purified by preparative HPLC to yield the expected peptide as a colorless powder.

\section{Induction of estrus}

Ovaries were monitored by transrectal ultrasonography to identify whether the corpus luteum (CL) was present. If the presence of CL was confirmed, $25 \mathrm{mg}$ of dinoprost $\left(\mathrm{PGF}_{2 \alpha}\right.$, Veterinary Pronalgon ${ }^{\circledR}-\mathrm{F}$ Injection; Pfizer Japan, Tokyo, Japan) was injected intramuscularly to regress the $\mathrm{CL}$ and induce estrus. After $\mathrm{PGF}_{2 \alpha}$ injection, $\mathrm{CL}$ regression and follicular growth, the behaviors of cows were observed every day until they showed standing estrus. The day of standing estrus was designated as the day of estrus (Day 0).

\section{Bovine Kp-53 administration and blood sampling}

The effects of bovine Kp-53 on gonadotropin secretion were examined. Saline $(\mathrm{n}=4)$ or bovine Kp-53 in $6 \mathrm{ml}$ saline $(0.2 \mathrm{nmol} /$ $\mathrm{kg}, \mathrm{n}=3$, or $2 \mathrm{nmol} / \mathrm{kg}, \mathrm{n}=4$ ) was injected intravenously at 1200 $\mathrm{h}$ on Day 5 when the dominant follicle (DF) of the first follicular wave (first DF) had been selected. Doses of Kp-53 were selected in a pilot study because equivalent doses of kisspeptin C-terminal decapeptide (Kp-10) administration intravenously stimulated LH secretion in steers (data not shown). Whitlock et al. [22] also reported that bolus intravenous injection of $\mathrm{Kp}-10$ at $0.1 \mathrm{nmol} / \mathrm{kg}$ stimulated LH secretion in ovariectomized cows treated with estradiol and progesterone. Blood samples $(2 \mathrm{ml})$ were collected every $10 \mathrm{~min}$ for $8 \mathrm{~h}$, starting at $4 \mathrm{~h}$ prior to injection. Plasma was separated and stored at $-30 \mathrm{C}$ until $\mathrm{LH}$ and $\mathrm{FSH}$ assays.

\section{Ultrasonography}

The effects of bovine Kp-53 on ovarian activity were examined. Ovarian antral follicles were monitored by transrectal ultrasonography using a 7.5-MHz transrectal linear probe (HS-1500, Honda Electronics, Toyohashi, Japan). Transrectal ultrasonography was performed once daily at $1800 \mathrm{~h}$ during one complete estrous cycle beginning on Day 0 , and an additional observation was conducted at $0600 \mathrm{~h}$ from Day 5 (the day of injection) to Day 7. Ovaries were scanned in several planes, and ultrasonic images were recorded when the follicle size was greater than $5 \mathrm{~mm}$ in diameter at the widest axis of the follicle. The follicular diameter of each follicle was determined from the ultrasonographic images as an average of the widest diameter of the follicle and the length perpendicular to the widest diameter. The ruler function of Adobe Illustrator CS3 (Adobe Systems, San Jose, CA, USA) was used to measure the diameter from the ultrasonographic images, and the measured follicular diameter was calibrated to the actual size from the scale marked in each image. Ovulation was confirmed as the disappearance of an identified DF ( $\geq 9 \mathrm{~mm})$ and the subsequent appearance of the CL.

\section{Radioimmunoassays for $\mathrm{LH}$ and FSH}

Plasma LH concentrations were determined by a double-antibody radioimmunoassay (RIA) with a bovine LH RIA kit provided by the National Hormone and Peptide Program (NHPP; Baltimore, MD, USA). Highly purified bovine LH (AFP-11743) was used for iodination and cold standard. Rabbit anti-ovine LH serum (YM \#18) [23] was used as the primary antibody diluted 1:80,000 in RIA buffer [50 mM phosphate buffer containing $100 \mathrm{mM} \mathrm{NaCl}$ and $0.1 \%$ sodium azide (pH 7.5)] with $50 \mathrm{mM}$ EDTA $2 \mathrm{Na}$ and $2 \%$ normal rabbit serum. Anti-rabbit gamma globulin goat serum (ARGG), developed in our laboratory, was used as the secondary antibody in RIA buffer with 50 mM EDTA $2 \mathrm{Na}$ and $3 \%$ polyethylene glycol. The bovine LH standard was diluted using RIA buffer with $1 \%$ bovine serum albumin (BSA) to a concentration between $0.0049 \mathrm{ng} / 100 \mu \mathrm{l}$ and $1.25 \mathrm{ng} / 100 \mu \mathrm{l}$. Aliquots $(50 \mu \mathrm{l})$ of unknown samples were diluted with $50 \mu \mathrm{l}$ of RIA buffer with $1 \%$ BSA. Standard and unknown samples were mixed with $50 \mu \mathrm{l}$ of anti-ovine LH solution and incubated at $4 \mathrm{C}$. After 48 $\mathrm{h}$ of incubation, ${ }^{125} \mathrm{I}$-labeled bovine $\mathrm{LH}(5,000$ to $7,000 \mathrm{cpm} / 100 \mu \mathrm{l})$ in RIA buffer with $0.1 \%$ BSA was added to each tube and incubated for $48 \mathrm{~h}$ at $4 \mathrm{C}$, and $\mathrm{ARGG}$ solution was then added to each tube. After incubation for $48 \mathrm{~h}$ at $4 \mathrm{C}$, samples were centrifuged, and the radioactivity in the precipitates was counted with a gamma counter (ARC-1000M; Hitachi Aloka Medical, Tokyo, Japan). The lowest detectable LH concentration was $0.098 \mathrm{ng} / \mathrm{ml}$ in a $50-\mu 1$ plasma sample. Intra- and inter-assay coefficients of variation were $10.4 \%$ at $0.56 \mathrm{ng} / \mathrm{ml}$ and $8.0 \%$ at $0.61 \mathrm{ng} / \mathrm{ml}$, respectively.

Plasma FSH concentrations were determined by a double-antibody RIA with a bovine FSH RIA kit provided by the NHPP using rabbit anti-ovine FSH serum (NIDDK-anti-oFSH-1), and data were expressed in terms of AFP-5332B. The RIA procedure was performed as described above. The bovine FSH standard was diluted to a concentration between $0.0049 \mathrm{ng} / 100 \mu \mathrm{l}$ and $1.25 \mathrm{ng} / 100 \mu \mathrm{l}$. The lowest detectable FSH concentration was $0.098 \mathrm{ng} / \mathrm{ml}$ in a $50-\mu 1$ plasma sample. The intra- and inter-assay coefficients of variation were $11.8 \%$ at $0.56 \mathrm{ng} / \mathrm{ml}$ and $8.4 \%$ at $0.55 \mathrm{ng} / \mathrm{ml}$, respectively. 
A
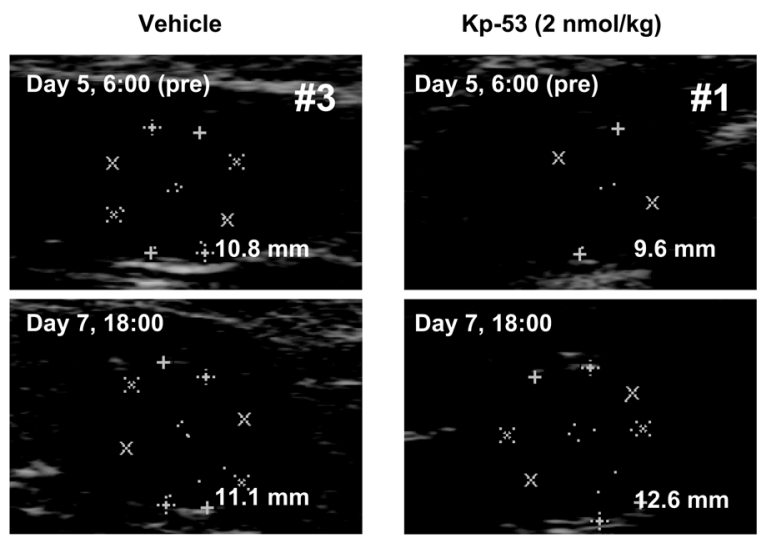

C

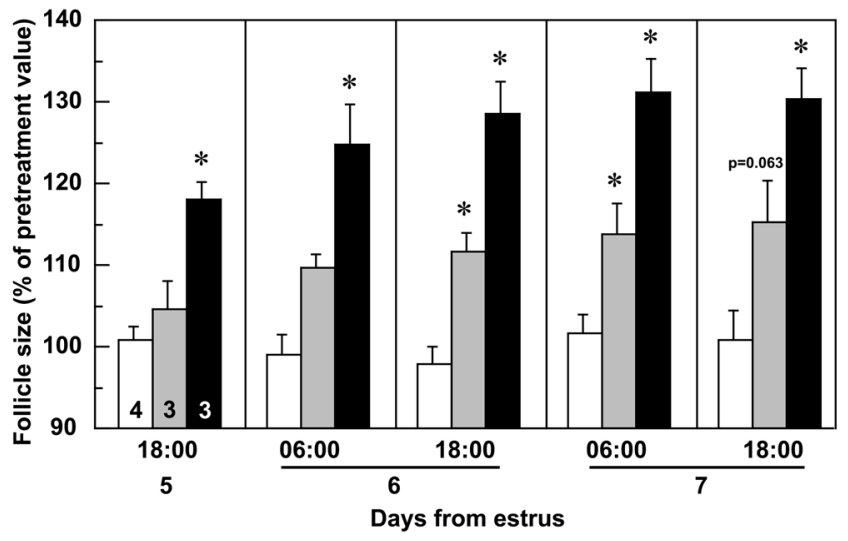

\section{Statistical analysis}

The actual follicle size in diameter at $0600 \mathrm{~h}$ on Day 5 (before injection) was compared between groups, and significant differences were determined by one-way ANOVA followed by Dunnett's post hoc comparison tests. Follicular growth of non-ovulated follicles after Kp-53 injection was expressed as the percentage of the mean follicular diameter before injection on Day 5. Significant differences between groups were determined by one-way ANOVA followed by Dunnett's post hoc comparison tests. The area under the curve (AUC) of each plasma LH and FSH profile was calculated with the trapezoidal rule during each 2-h sampling period before ( -4 to $-2 \mathrm{~h}$ and -2 to $0 \mathrm{~h}$ ) and after ( 0 to $2 \mathrm{~h}$ and 2 to $4 \mathrm{~h}$ ) injection. Significant differences between the values of just prior to injection ( -2 to $0 \mathrm{~h}$ ) and those of the other periods were determined by one-way ANOVA followed by Dunnett's test.

\section{Results}

Effects of intravenous injection of Kp-53 on ovarian activity In 1 out of 4 cows treated with $2 \mathrm{nmol} / \mathrm{kg}$ of Kp-53, the first DF

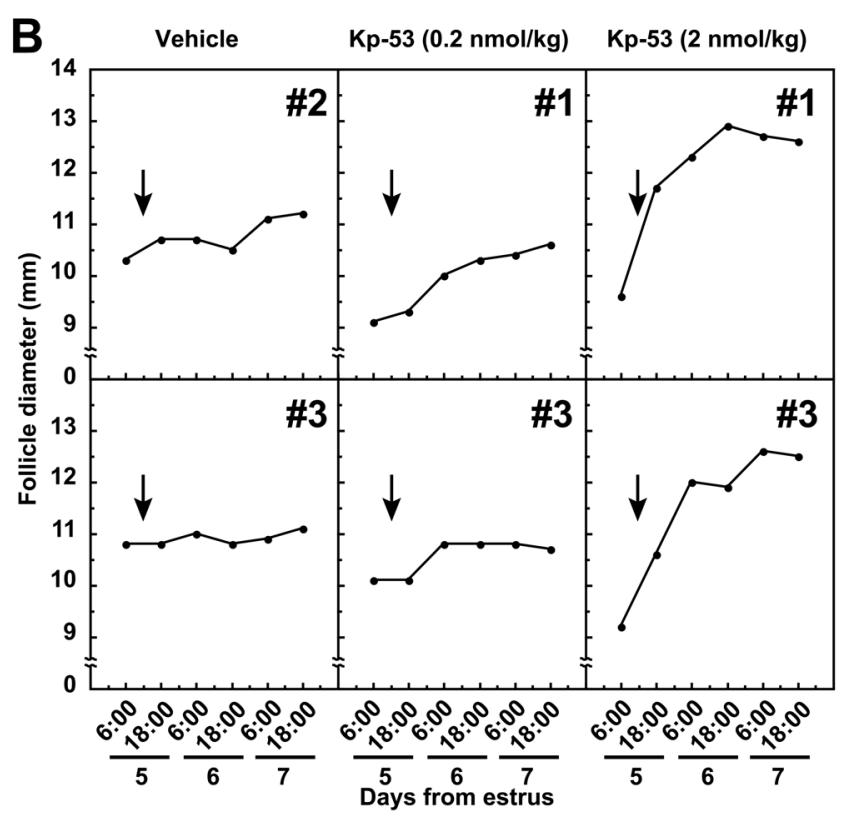

Fig. 1. Effects of full-length kisspeptin (Kp-53) injection on ovarian follicles in adult beef cows. A: Representative ultrasound images of the ovaries in non-ovulatory cows treated with vehicle or Kp-53 $(2 \mathrm{nmol} / \mathrm{kg}$ ) at $0600 \mathrm{~h}$ on Day 5 (before injection) and at $1800 \mathrm{~h}$ on Day 7 (after injection). The day of standing estrus was designated as the day of estrus (Day 0). B: Two representative profiles of changes in follicle diameter in non-ovulatory cows treated with vehicle or Kp-53. The arrows indicate the time of intravenous injection of vehicle or Kp-53 (0.2 or $2 \mathrm{nmol} / \mathrm{kg})$. C: Mean $( \pm$ SEM) percent changes in follicle size in non-ovulatory cows after vehicle (open columns) or Kp-53 (shaded columns, $0.2 \mathrm{nmol} /$ $\mathrm{kg}$; solid columns, $2 \mathrm{nmol} / \mathrm{kg}$ ) injection. Values are expressed as percent changes in the mean follicular diameter at $0600 \mathrm{~h}$ on Day 5 . The numbers in each column indicate the number of animals used. * $\mathrm{P}<0.05 v s$. vehicle injection (Dunnett's test).

ovulated within $30 \mathrm{~h}$ of the injection (Supplementary Fig. S1A: on-line only). None of the animals treated with $0.2 \mathrm{nmol} / \mathrm{kg}$ of $\mathrm{Kp}-53$ or vehicle ovulated after injection. In non-ovulated cows after injection of $2 \mathrm{nmol} / \mathrm{kg} \mathrm{Kp}-53$, follicular diameter increased (Figs. $1 \mathrm{~A}$ and $1 \mathrm{~B}$ ). Injection of Kp-53 at $0.2 \mathrm{nmol} / \mathrm{kg}$ resulted in a slight increase in follicular diameter. The follicular diameters at $0600 \mathrm{~h}$ on Day 5 (pretreatment) were $11.08 \pm 0.40,9.47 \pm 0.32$, and $9.10 \pm$ $0.32 \mathrm{~mm}$ in the vehicle-, Kp-53 (0.2 nmol/ $\mathrm{kg})-$ and $\mathrm{Kp}-53(2 \mathrm{nmol} /$ $\mathrm{kg})$-treated groups, respectively. Because there were significant differences $(\mathrm{P}<0.05)$ in follicle diameter between the vehicle- and Kp-53 ( 0.2 or $2 \mathrm{nmol} / \mathrm{kg})$-treated groups, follicular development in cows after Kp-53 injection was evaluated as the percentage of the pretreatment value (Fig. 1C). Follicular growth accelerated in cows treated with $2 \mathrm{nmol} / \mathrm{kg}$ of Kp-53 after injection, and the size of the first DF was significantly increased $(\mathrm{P}<0.05)$ at $1800 \mathrm{~h}$ on Day 5 and thereafter. The follicular size in animals injected with $0.2 \mathrm{nmol} /$ $\mathrm{kg}$ of $\mathrm{Kp}-53$ was also significantly increased $(\mathrm{P}<0.05)$ at $1800 \mathrm{~h}$ on Day 6 and $0600 \mathrm{~h}$ on Day 7 but not at $1800 \mathrm{~h}$ on Day $7(\mathrm{P}=0.063)$. 

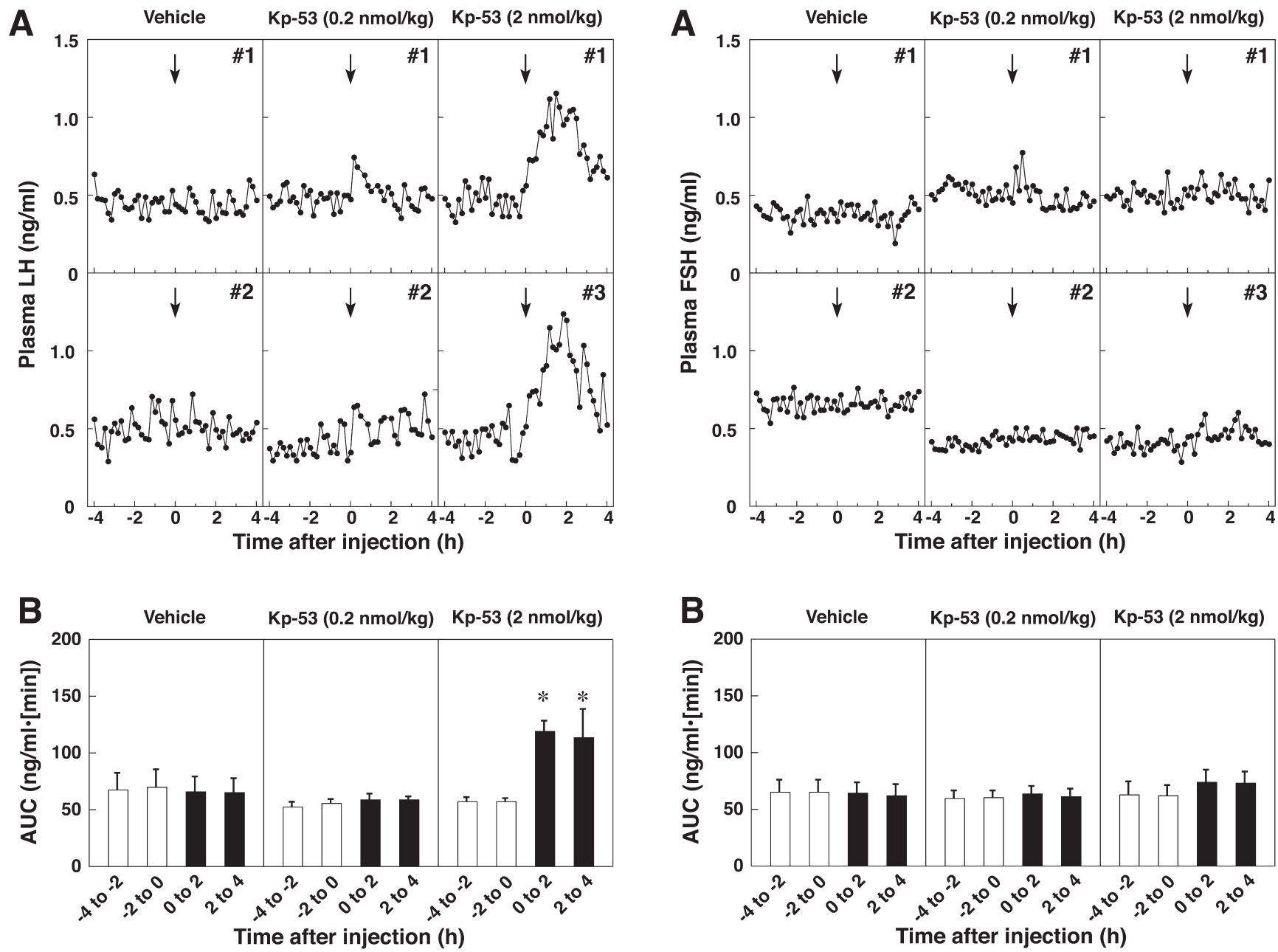

Fig. 2. Effects of full-length kisspeptin (Kp-53) injection on LH secretion in adult beef cows. A: Two representative profiles of plasma LH concentrations before and after intravenous injection of $\mathrm{Kp}-53$. The arrows indicate the time of intravenous injection of vehicle or $\mathrm{Kp}-53(0.2$ or $2 \mathrm{nmol} / \mathrm{kg})$. Blood samples were collected every $10 \mathrm{~min}$ for $8 \mathrm{~h}$ beginning $4 \mathrm{~h}$ before injection. B: Mean ( \pm SEM) areas under the curve (AUCs) of LH profiles during every 2-h sampling period before (open columns) and after (solid columns) injection. ${ }^{*} \mathrm{P}<0.05 v s$. the value just prior to injection ( -2 to $0 \mathrm{~h}$ ).

\section{Effects of intravenous injection of Kp-53 on gonadotropin} secretion

Treatment with $2 \mathrm{nmol} / \mathrm{kg}$ of Kp-53 resulted in a sustained increase in the plasma LH concentrations for a few hours after injection (Fig. $2 \mathrm{~A}$ and Supplementary Fig. S1B). Injection with $0.2 \mathrm{nmol} / \mathrm{kg}$ of Kp-53 had little or no effect on the plasma LH profiles. No injections at any dose of bovine Kp-53 changed the plasma FSH concentrations (Fig. 3A). Statistical analysis revealed that the AUCs during the 2-h sampling periods ( 0 to $2 \mathrm{~h}$ and 2 to $4 \mathrm{~h}$ ) for the LH secretory response to $2 \mathrm{nmol} / \mathrm{kg}$ of bovine $\mathrm{Kp}-53$ treatment were significantly higher $(\mathrm{P}<0.05)$ than the pretreatment value (Fig. 2B). Animals treated with bovine $\mathrm{Kp}-53$ at $0.2 \mathrm{nmol} / \mathrm{kg}$ showed no significant increase after injection. The AUC of FSH secretory response to Kp-53 did not show

Fig. 3. Effects of full-length kisspeptin (Kp-53) injection on FSH secretion in adult beef cows. A: Two representative profiles of plasma FSH concentrations before and after intravenous injection of $\mathrm{Kp}-53$. The arrows indicate the time of intravenous injection of vehicle or $\mathrm{Kp}-53(0.2$ or $2 \mathrm{nmol} / \mathrm{kg})$. Blood samples were collected every $10 \mathrm{~min}$ for $8 \mathrm{~h}$ beginning $4 \mathrm{~h}$ before injection. B: Mean $( \pm$ SEM) areas under the curve (AUCs) of FSH profiles during every 2-h sampling period before (open columns) and after (solid columns) injection.

a significant change after peptide injection at any dose (Fig. 3A and 3B). In 1 out of 4 cows whose first DF ovulated after $2 \mathrm{nmol} / \mathrm{kg}$ of Kp-53 treatment, the plasma LH concentrations increased to over $2 \mathrm{ng} / \mathrm{ml}$ at $2 \mathrm{~h}$ after the injection and were higher than those in the other groups (Supplementary Fig. S1B).

\section{Discussion}

The present study demonstrates that follicular development is facilitated in cows administered peripherally with full-length kisspeptin. Administration of $2 \mathrm{nmol} / \mathrm{kg}$ of $\mathrm{Kp}-53$ induced elevation of $\mathrm{LH}$ concentrations from the basal level for up to $4 \mathrm{~h}$, and the LH response to kisspeptin administration reflects the response of 
follicular growth after the kisspeptin injection. On the other hand, the size of the first DF increased after administration of $0.2 \mathrm{nmol} / \mathrm{kg}$ of Kp-53, although the concentrations of LH were not elevated after the injection. The follicular growth of the first DF in the latter case may be ascribed to normal growth in the DF because the follicular diameter at $0600 \mathrm{~h}$ on Day 5 (pretreatment) in Kp-53 $(0.2 \mathrm{nmol} /$ $\mathrm{kg}$ )-treated cows was significantly smaller than that in the vehicletreated animals. The pretreatment size of the first DF in the Kp-53 ( $2 \mathrm{nmol} / \mathrm{kg})$-treated cows was equivalent to that in the Kp-53 (0.2 $\mathrm{nmol} / \mathrm{kg}$ )-treated animals, suggesting that the further acceleration of follicular growth in $\mathrm{Kp}-53(2 \mathrm{nmol} / \mathrm{kg})$-treated cows was due to the kisspeptin-induced LH secretion in the present study. A previous study had shown that a continuous $\mathrm{Kp}-10$ infusion elicited a prolonged $\mathrm{LH}$ release and then estrogen secretion, followed by the preovulatory $\mathrm{LH}$ surge in acyclic ewes [24]. Although little FSH release was stimulated by kisspeptin treatment in the present study, it may be that follicle development is stimulated by the action of LH but not FSH after DF selection, as previously reported [25]. Our study also showed that administration of $2 \mathrm{nmol} / \mathrm{kg}$ of Kp-53 induced ovulation of the first DF in 1 out of 4 cows, but ovulation of the first DF did not occur in the rest of the cows. Although we do not know the reason for the different follicular response to the administration of a high dose of $\mathrm{Kp}-53$, a possible mechanism of ovulation induction of the first DF after full-length kisspeptin treatment is higher concentrations of LH secretion occurring after administration (Supplementary Fig. S1B), which in turn causes ovulation (as previously reported in rats [26] and ewes [17]), than those in the other non-ovulated cows. Overall, it seems to be likely that, for clinical application in veterinary therapy, a single iv dose of Kp-53 between 0.2 to $2 \mathrm{nmol} / \mathrm{kg}$ is appropriate for stimulation of follicular growth without ovulation. Further, it might be advantageous to apply kisspeptin with infusions or repetitive injections for such purpose.

The action sites of peripherally injected kisspeptin could be the nerve terminals of GnRH neurons located in the median eminence (ME). Morphological evidence [27-29] has shown that kisspeptin neuronal fibers are closely associated with GnRH fibers in the ME. GnRH release is stimulated by kisspeptin treatment from ME tissue cultures in vitro [30]. Since the ME is one of the circumventricular organs outside the blood-brain barrier [31], peripherally injected kisspeptin would stimulate GnRH release by direct action on the GnRH neuronal terminals. There are other candidates for the action site of peripherally injected kisspeptin. GPR54 mRNA and GPR54 protein are expressed in the brain as well as in the pituitary gland $[32,33]$ and in the ovaries [34, 35]; however, the physiological roles of GPR54 in these tissues are still unclear. In addition, some studies have reported that in vitro application of $\mathrm{Kp}-10$ stimulates $\mathrm{LH}$ release from pituitary cells in rats [36], pigs [37], sheep [38], cattle [37] and primates [39]. However, the stimulatory effects of kisspeptin administration on LH secretion do not occur in hypothalamo-pituitarydisconnected ewes [38].

In the present study, FSH secretion was not induced after injections with Kp-53. There are 2 points of view concerning the reason for the lack of effect of Kp-53 on FSH secretion. First, synthesis and/ or release of FSH could be affected by inhibitory factors, such as inhibin, from the DF in the ovary [40]. In this study, because Kp-53 was injected on Day 5 when a DF had been selected, inhibin might have been secreted from the larger follicle and blocked synthesis and/ or release of FSH. Second, this may be ascribed to an insufficient release of $\mathrm{GnRH}$ induced by peripherally injected kisspeptin to stimulate FSH secretion. Navarro et al. [41] showed that the FSH secretory response to centrally injected kisspeptin is approximately 100 -fold less sensitive than the LH response in male rats. The lower sensitivity of the FSH response to kisspeptin injection may be because kisspeptin induces a small amount of GnRH release and then LH secretion, and this injection may not be enough to induce FSH secretion. However, a previous study showed that peripheral injection of human $\mathrm{Kp}-10$ induced FSH secretion in prepubertal cattle [42]. The reason why Kp-53 did not stimulate FSH secretion in the present study could be the differences in the animal model examined, since we used ovary-intact cows.

The present study suggests that kisspeptin or related peptides could be used as novel compounds controlling ovarian activity in domestic animals. The close relationship between follicle size at insemination and pregnancy success has been reported in beef cows [43]. Busch et al. [44] showed that progesterone secretion after GnRH-induced small follicle ovulation decreased compared with that after GnRH-induced large follicle ovulation or spontaneous ovulation. Nonpregnant cows had lower serum concentrations of progesterone beginning at 10 days post insemination compared with pregnant cows [44]. These reports suggest that induction of immature follicle ovulation by $\mathrm{GnRH}$ retains the risk of reduction in conception rate after artificial insemination. In the present study, follicular development of the first DF was facilitated in cows administered kisspeptin. Thus, kisspeptin may be useful in resolving the problems caused by GnRH-induced ovulation of small follicles. From this standpoint, more potent kisspeptin derivatives are required for practical use in cows to stimulate gonadotropin secretion and follicular development. It has been demonstrated that the kisspeptin $\mathrm{C}$-terminal pentapeptide is the pharmacophore that activates GPR54 [45] and that the pentapeptide derivatives have potent agonistic activity [46]. Recently, it was shown that novel GPR54 agonists stimulated LH secretion when the pentapeptide derivatives were injected locally into the preoptic area where GnRH neurons are located in rats [47].

In conclusion, we found that follicular development of the first DF accelerated in cows treated peripherally with full-length bovine kisspeptin. This effect was mediated by LH release induced by kisspeptin injection. Full-length kisspeptin is also capable of inducing ovulation. Thus, kisspeptin or related peptides might be advantageous for potential usage as novel drugs for stimulating follicular development and ovulation.

\section{Acknowledgments}

The authors are deeply grateful to Dr AF Parlow and the National Hormone and Peptide Program for reagents used in the $\mathrm{LH}$ and FSH RIA and to Dr T Tanaka, Tokyo University of Agriculture and Technology, for providing technical guidance regarding ultrasonography. We also thank Mr N Inagaki, Ms K Yamasaki, Mr Y Kono, Mr N Yamamoto and Ms K Miyazaki for their technical assistance. The radioimmunoassays were performed at the Nagoya University Radioisotope Center. This work was supported in part by the Program for Promotion of Basic Research Activities 
for Innovative Biosciences (PROBRAIN) of Japan, the Research Program on Innovative Technologies for Animal Breeding, Reproduction and Vaccine Development (REP2003 and REP2005) of the Ministry of Agriculture, Forestry and Fisheries of Japan and Grants-in-Aid for Japan Society for the Promotion of Science (JSPS) Fellows (to YN; No. 24-10489) and for Scientific Research (to SO; 23658223 and 24380154) from the JSPS.

\section{References}

1. Moenter SM, Brand RM, Midgley AR, Karsch FJ. Dynamics of gonadotropinreleasing hormone release during a pulse. Endocrinology 1992; 130: 503-510. [Medline] [CrossRef]

2. Knobil E. The neuroendocrine control of the menstrual cycle. Recent Prog Horm Res 1980; 36: 53-88. [Medline]

3. Lehman MN, Merkley CM, Coolen LM, Goodman RL. Anatomy of the kisspeptin neural network in mammals. Brain Res 2010; 1364: 90-102. [Medline] [CrossRef]

4. Smith JT. Sex steroid control of hypothalamic Kiss 1 expression in sheep and rodents: comparative aspects. Peptides 2009; 30: 94-102. [Medline] [CrossRef]

5. Maeda K, Ohkura S, Uenoyama Y, Wakabayashi Y, Oka Y, Tsukamura H, Okamura H. Neurobiological mechanisms underlying GnRH pulse generation by the hypothalamus. Brain Res 2010; 1364: 103-115. [Medline] [CrossRef]

6. Gottsch ML, Cunningham MJ, Smith JT, Popa SM, Acohido BV, Crowley WF, Seminara S, Clifton DK, Steiner RA. A role for kisspeptins in the regulation of gonadotropin secretion in the mouse. Endocrinology 2004; 145: 4073-4077. [Medline] [CrossRef]

7. Irwig MS, Fraley GS, Smith JT, Acohido BV, Popa SM, Cunningham MJ, Gottsch ML, Clifton DK, Steiner RA. Kisspeptin activation of gonadotropin releasing hormone neurons and regulation of KiSS-1 mRNA in the male rat. Neuroendocrinology 2004; 80: 264-272. [Medline] [CrossRef]

8. Messager S, Chatzidaki EE, Ma D, Hendrick AG, Zahn D, Dixon J, Thresher RR, Malinge I, Lomet D, Carlton MB, Colledge WH, Caraty A, Aparicio SA. Kisspeptin directly stimulates gonadotropin-releasing hormone release via G protein-coupled receptor 54. Proc Natl Acad Sci USA 2005; 102: 1761-1766. [Medline] [CrossRef]

9. d'Anglemont de Tassigny X, Fagg LA, Dixon JP, Day K, Leitch HG, Hendrick AG, Zahn D, Franceschini I, Caraty A, Carlton MB, Aparicio SA, Colledge WH. Hypogonadotropic hypogonadism in mice lacking a functional Kiss1 gene. Proc Natl Acad Sci USA 2007; 104: 10714-10719. [Medline] [CrossRef]

10. Lapatto R, Pallais JC, Zhang D, Chan YM, Mahan A, Cerrato F, Le WW, Hoffman GE, Seminara SB. Kiss $1^{-/-}$mice exhibit more variable hypogonadism than $\operatorname{Gpr} 54^{-/-}$mice. Endocrinology 2007; 148: 4927-4936. [Medline] [CrossRef]

11. Seminara SB, Messager S, Chatzidaki EE, Thresher RR, Acierno JS Jr, Shagoury JK, Bo-Abbas Y, Kuohung W, Schwinof KM, Hendrick AG, Zahn D, Dixon J, Kaiser UB, Slaugenhaupt SA, Gusella JF, O'Rahilly S, Carlton MB, Crowley WF Jr, Aparicio SA, Colledge WH. The GPR54 gene as a regulator of puberty. N Engl J Med 2003; 349: 1614-1627. [Medline] [CrossRef]

12. de Roux N, Genin E, Carel JC, Matsuda F, Chaussain JL, Milgrom E. Hypogonadotropic hypogonadism due to loss of function of the KiSS1-derived peptide receptor GPR54. Proc Natl Acad Sci USA 2003; 100: 10972-10976. [Medline] [CrossRef]

13. Kinoshita M, Tsukamura H, Adachi S, Matsui H, Uenoyama Y, Iwata K, Yamada S, Inoue K, Ohtaki T, Matsumoto H, Maeda K. Involvement of central metastin in the regulation of preovulatory luteinizing hormone surge and estrous cyclicity in female rats. Endocrinology 2005; 146: 4431-4436. [Medline] [CrossRef]

14. Adachi S, Yamada S, Takatsu Y, Matsui H, Kinoshita M, Takase K, Sugiura H, Ohtaki T, Matsumoto H, Uenoyama Y, Tsukamura H, Inoue K, Maeda K. Involvement of anteroventral periventricular metastin/kisspeptin neurons in estrogen positive feedback action on luteinizing hormone release in female rats. J Reprod Dev 2007; 53: 367-378. [Medline] [CrossRef]

15. Smith JT, Li Q, Sing Yap K, Shahab M, Roseweir AK, Millar RP, Clarke IJ. Kisspeptin is essential for the full preovulatory LH surge and stimulates GnRH release from the isolated ovine median eminence. Endocrinology 2011; 152: 1001-1012. [Medline] [CrossRef]

16. Tovar S, Vazquez MJ, Navarro VM, Fernandez-Fernandez R, Castellano JM, Vigo E, Roa J, Casanueva FF, Aguilar E, Pinilla L, Dieguez C, Tena-Sempere M. Effects of single or repeated intravenous administration of kisspeptin upon dynamic LH secretion in conscious male rats. Endocrinology 2006; 147: 2696-2704. [Medline] [CrossRef]

17. Caraty A, Smith JT, Lomet D, Ben Said S, Morrissey A, Cognie J, Doughton B, Baril G, Briant C, Clarke IJ. Kisspeptin synchronizes preovulatory surges in cyclical ewes and causes ovulation in seasonally acyclic ewes. Endocrinology 2007; 148: 5258-5267. [Medline] [CrossRef]
18. Plant TM, Ramaswamy S, Dipietro MJ. Repetitive activation of hypothalamic G protein-coupled receptor 54 with intravenous pulses of kisspeptin in the juvenile monkey (Macaca mulatta) elicits a sustained train of gonadotropin-releasing hormone discharges Endocrinology 2006; 147: 1007-1013. [Medline] [CrossRef]

19. Roseweir AK, Kauffman AS, Smith JT, Guerriero KA, Morgan K, Pielecka-Fortuna J, Pineda R, Gottsch ML, Tena-Sempere M, Moenter SM, Terasawa E, Clarke IJ, Steiner RA, Millar RP. Discovery of potent kisspeptin antagonists delineate physiological mechanisms of gonadotropin regulation. J Neurosci 2009; 29: 3920-3929. [Medline] [CrossRef]

20. Li XF, Kinsey-Jones JS, Cheng Y, Knox AM, Lin Y, Petrou NA, Roseweir A, Lightman SL, Milligan SR, Millar RP, O'Byrne KT. Kisspeptin signalling in the hypothalamic arcuate nucleus regulates GnRH pulse generator frequency in the rat. PLoS One 2009; 4: e8334. [Medline] [CrossRef]

21. Ohkura S, Takase K, Matsuyama S, Mogi K, Ichimaru T, Wakabayashi Y, Uenoyama Y, Mori Y, Steiner RA, Tsukamura H, Maeda KI, Okamura H. Gonadotrophin-releasing hormone pulse generator activity in the hypothalamus of the goat. J Neuroendocrinol 2009; 21: 813-821. [Medline] [CrossRef]

22. Whitlock BK, Daniel JA, Wilborn RR, Rodning SP, Maxwell HS, Steele BP, Sartin JL. Interaction of estrogen and progesterone on kisspeptin-10-stimulated luteinizing hormone and growth hormone in ovariectomized cows. Neuroendocrinology 2008; 88: 212-215. [Medline] [CrossRef]

23. Ohkura S, Ichimaru T, Itoh F, Matsuyama S, Okamura H. Further evidence for the role of glucose as a metabolic regulator of hypothalamic gonadotropin-releasing hormone pulse generator activity in goats. Endocrinology 2004; 145: 3239-3246. [Medline] [CrossRef]

24. Sébert ME, Lomet D, Said SB, Monget P, Briant C, Scaramuzzi RJ, Caraty A. Insights into the mechanism by which kisspeptin stimulates a preovulatory LH surge and ovulation in seasonally acyclic ewes: potential role of estradiol. Domest Anim Endocrinol 2010; 38: 289-298. [Medline] [CrossRef]

25. Lucy MC. The bovine dominant ovarian follicle. J Anim Sci 2007; 85: E89-E99. [Medline]

26. Matsui H, Takatsu Y, Kumano S, Matsumoto H, Ohtaki T. Peripheral administration of metastin induces marked gonadotropin release and ovulation in the rat. Biochem Biophys Res Commun 2004; 320: 383-388. [Medline] [CrossRef]

27. Ramaswamy S, Guerriero KA, Gibbs RB, Plant TM. Structural interactions between kisspeptin and GnRH neurons in the mediobasal hypothalamus of the male rhesus monkey (Macaca mulatta) as revealed by double immunofluorescence and confocal microscopy. Endocrinology 2008; 149: 4387-4395. [Medline] [CrossRef]

28. Uenoyama Y, Inoue N, Pheng V, Homma T, Takase K, Yamada S, Ajiki K, Ichikawa M, Okamura H, Maeda KI, Tsukamura H. Ultrastructural evidence of kisspeptingonadotrophin-releasing hormone interaction in the median eminence of female rats implication of axo-axonal regulation of GnRH release. J Neuroendocrinol 2011; 23 863-870. [Medline] [CrossRef]

29. Matsuyama S, Ohkura S, Mogi K, Wakabayashi Y, Mori Y, Tsukamura H, Maeda K, Ichikawa M, Okamura H. Morphological evidence for direct interaction between kisspeptin and gonadotropin-releasing hormone neurons at the median eminence of the male goat: an immunoelectron microscopic study. Neuroendocrinology 2011; 94: 323-332. [Medline] [CrossRef]

30. d'Anglemont de Tassigny X, Fagg LA, Carlton MB, Colledge WH. Kisspeptin can stimulate gonadotropin-releasing hormone $(\mathrm{GnRH})$ release by a direct action at $\mathrm{GnRH}$ nerve terminals. Endocrinology 2008; 149: 3926-3932. [Medline] [CrossRef]

31. Johnson AK, Gross PM. Sensory circumventricular organs and brain homeostatic pathways. FASEB J 1993; 7: 678-686. [Medline]

32. Kotani M, Detheux M, Vandenbogaerde A, Communi D, Vanderwinden JM, Le Poul E, Brezillon S, Tyldesley R, Suarez-Huerta N, Vandeput F, Blanpain C, Schiffmann SN, Vassart G, Parmentier M. The metastasis suppressor gene KiSS-1 encodes kisspeptins, the natural ligands of the orphan $\mathrm{G}$ protein-coupled receptor GPR54. J Biol Chem 2001; 276: 34631-34636. [Medline] [CrossRef]

33. Richard N, Galmiche G, Corvaisier S, Caraty A, Kottler ML. KiSS-1 and GPR54 genes are co-expressed in rat gonadotrophs and differentially regulated in vivo by oestradiol and gonadotrophin-releasing hormone. J Neuroendocrinol 2008; 20: 381-393. [Medline] [CrossRef]

34. Terao Y, Kumano S, Takatsu Y, Hattori M, Nishimura A, Ohtaki T, Shintani Y. Expression of KiSS-1, a metastasis suppressor gene, in trophoblast giant cells of the rat placenta. Biochim Biophys Acta 2004; 1678: 102-110.

35. Castellano JM, Gaytan M, Roa J, Vigo E, Navarro VM, Bellido C, Dieguez C, Aguilar E, Sanchez-Criado JE, Pellicer A, Pinilla L, Gaytan F, Tena-Sempere M. Expression of KiSS-1 in rat ovary: putative local regulator of ovulation? Endocrinology 2006; 147: 4852-4862. [Medline] [CrossRef]

36. Navarro VM, Castellano JM, Fernandez-Fernandez R, Tovar S, Roa J, Mayen A, Nogueiras R, Vazquez MJ, Barreiro ML, Magni P, Aguilar E, Dieguez C, Pinilla L, Tena-Sempere M. Characterization of the potent luteinizing hormone-releasing activity 
of KiSS-1 peptide, the natural ligand of GPR54. Endocrinology 2005; 146: 156-163. [Medline] [CrossRef]

37. Suzuki S, Kadokawa H, Hashizume T. Direct kisspeptin-10 stimulation on luteinizing hormone secretion from bovine and porcine anterior pituitary cells. Anim Reprod Sci 2008; 103: 360-365. [Medline] [CrossRef]

38. Smith JT, Rao A, Pereira A, Caraty A, Millar RP, Clarke IJ. Kisspeptin is present in ovine hypophysial portal blood but does not increase during the preovulatory luteinizing hormone surge: evidence that gonadotropes are not direct targets of kisspeptin in vivo. Endocrinology 2008; 149: 1951-1959. [Medline] [CrossRef]

39. Luque RM, Cordoba-Chacon J, Gahete MD, Navarro VM, Tena-Sempere M, Kineman RD, Castano JP. Kisspeptin regulates gonadotroph and somatotroph function in nonhuman primate pituitary via common and distinct signaling mechanisms. Endocrinology 2011; 152: 957-966. [Medline] [CrossRef]

40. Mihm M, Evans AC. Mechanisms for dominant follicle selection in monovulatory species: a comparison of morphological, endocrine and intraovarian events in cows, mares and women. Reprod Domest Anim 2008; 43(Suppl 2): 48-56. [Medline] [CrossRef]

41. Navarro VM, Castellano JM, Fernandez-Fernandez R, Tovar S, Roa J, Mayen A, Barreiro ML, Casanueva FF, Aguilar E, Dieguez C, Pinilla L, Tena-Sempere M. Effects of KiSS-1 peptide, the natural ligand of GPR54, on follicle-stimulating hormone secretion in the rat. Endocrinology 2005; 146: 1689-1697. [Medline] [CrossRef]

42. Ezzat Ahmed A, Saito H, Sawada T, Yaegashi T, Yamashita T, Hirata T, Sawai K,
Hashizume T. Characteristics of the stimulatory effect of kisspeptin-10 on the secretion of luteinizing hormone, follicle-stimulating hormone and growth hormone in prepubertal male and female cattle. J Reprod Dev 2009; 55: 650-654. [Medline] [CrossRef]

43. Perry GA, Smith MF, Lucy MC, Green JA, Parks TE, MacNeil MD, Roberts AJ, Geary TW. Relationship between follicle size at insemination and pregnancy success Proc Natl Acad Sci USA 2005; 102: 5268-5273. [Medline] [CrossRef]

44. Busch DC, Atkins JA, Bader JF, Schafer DJ, Patterson DJ, Geary TW, Smith MF. Effect of ovulatory follicle size and expression of estrus on progesterone secretion in beef cows. J Anim Sci 2008; 86: 553-563. [Medline] [CrossRef]

45. Niida A, Wang Z, Tomita K, Oishi S, Tamamura H, Otaka A, Navenot JM, Broach JR, Peiper SC, Fujii N. Design and synthesis of downsized metastin (45-54) analogs with maintenance of high GPR54 agonistic activity. Bioorg Med Chem Lett 2006; 16: 134-137. [Medline] [CrossRef]

46. Tomita K, Oishi S, Ohno H, Peiper SC, Fujii N. Development of novel G-proteincoupled receptor 54 agonists with resistance to degradation by matrix metalloproteinase. $J$ Med Chem 2008; 51: 7645-7649. [Medline] [CrossRef]

47. Oishi S, Misu R, Tomita K, Setsuda S, Masuda R, Ohno H, Naniwa Y, Ieda N, Inoue N, Ohkura S, Uenoyama Y, Tsukamura H, Maeda K, Hirasawa A, Tsujimoto G, Fujii N. Activation of neuropeptide FF receptors by kisspeptin receptor ligands. ACS Med Chem Lett 2011; 2: 53-57. [CrossRef] 